\title{
PELATIHAN PENULISAN OPINI UNTUK GURU BAHASA INDONESIA MA NU TASYWIQUTH THULLAB SALAFIYYAH KUDUS
}

\author{
Muhammad Noor Ahsin, Eko Widianto \\ Fakultas Keguruan dan Ilmu Pendidikan, Universitas Muria Kudus \\ Email: noor.ahsin@umk.ac.id,eko.widianto@umk.ac.id
}

\begin{abstract}
ABSTRAK
Menulis opini bagi guru sangat penting. Untuk meningkatkan kompetensi guru perlu membuat karya tulis berupa tulisan popular salah satunya menulis artikel atau opini. Oleh karena itu, guru di sekolah SMA/ $M A$ Sederajat dituntut untuk cakap membuat media pembelajaran interaktif, termasuk guru di MA NU Tasywiquth Thullab Salafiyyah (TBS) Kudus. Pemasalahannya, tidak semua guru bisa menulis dengan baik. Guru bahasa Indonesia di sekolah tersebut ada banyak. Akan tetapi yang memiliki kemampuan menulis bagus belum banyak. Dengan kata lain masih harus banyak belajar dan praktik menulis secara langsung. Berdasarkan wawancara, guru bahasa Indonesia di MA NU TBS, menulis bagi mereka sangat penting. Apalagi Tuntutan kurikulum 2013. Namun Di Sekolah tersebut guru masib kesulitan membuat tulisan opini yang baik. Berdasarkan persamahan tersebut, maka dilaksanakanlah pengabdian masyarakat berupa pendampingan dan pelatihan menulis opin untuk guru bahasa Indonesia di MANU TBS Kudus. Pengabdian masyarakat ini dilaksanakan dengan menggunakan pendekatan asset based community development (ABCD). Kegiatan ini terlaksana dengan baik. Setelah pelatihan dan pendampingan kemampuan guru dalam menulis opini menjadi lebih baik. Indikator lain pelaksanaan pengandian kepada masyarakat ini hasil dari para subjek dampingan, sebagian besar menyatakan bahwa kemampuan menulis guru meningkat dan pelatihan ini sangat bermanfaat.
\end{abstract}

Kata kunci: Pelatihan, Menulis Opini, $A B C D$

\begin{abstract}
Writing opinions for teachers is very important. To improve the competence of teachers, it is necessary to write popular writing such as writing articles or opinions. Therefore, teachers in high school / $M A$ equivalent schools are required to be able to create interactive learning media, including teachers at MANU Tasywiquth Thullab Salafiyyah (TBS) Kudus. The problem is, not all teachers can write well. There are many Indonesian language teachers in the school. However, not many who have good writing skills.In other words there is still much to learn and practice writing directly. Based on interviews, Indonesian language teachers at MA NU TBS, writing for
\end{abstract}


them is very important. Moreover, the demands of the 2013 curriculum. However, in these schools, teachers still have difficulty making good opinion writing. Based on this greeting, community service was carried out in the form of mentoring and training to write opinions for Indonesian language teachers at MANU TBS Kudus. This community service is carried out using the asset based community development ( $A B C D)$ approach. This activity was carried out well. After training and mentoring the teacher's ability to write opinions becomes better. Other indicators of community coding are the results of the assisted subjects, most of whom stated that the teacher's writing ability was improved and the training was very useful.

Keywords:Training, Writing Opinion, $A B C D$

\section{PENDAHULUAN}

Menulis opini berarti memberikan wawasan dan pengetahuan untuk orang lain. Berbagai informasi, data, juga pengalaman. Karena itulah, kegiatan menulis opini mestinya kegiatan yang dilakukan dengan hati. Dengan kesukacitaan, kegembiraan membagi gagasan dan kecintaan menyumbangkan ilmu dan pengetahuan.

Menulis opini adalah kegiatan yang menyenangkan. Siapa pun sesungguhnya bisa dan mampu untuk menulis opini. Setiap orang yang memiliki pengetahuan, mampu menulis, sesungguhnya ia bisa menulis opini. Dengan opini, tidak saja gagasan itu bisa menyebar, tapi juga, antara lain, membuat ia dikenal, juga mendapat honorarium.

Menulis opini berarti menyebarluaskan gagasan. Dengan menulis opini, maka seseorang / guru berarti mentransfer ide dan gagasannya ke ruang publik. Ia masuk ke ranah publik, dan berusaha mempengaruhi publik, dengan tujuan akhir, gagasannya diterima atau juga diperdebatkan. Dan ia siap untuk itu.Karena itulah, menulis opini sesungguhnya adalah melakukan "rekreasi intelektual", mengasah otak, menajamkan pikiran, menantang munculnya ide-ide baru, juga menantang pendapat orang dengan argumentasi yang siap untuk diperdebatkan. Ide itu dapat tanpa diminta dalam kondisi bagaimana pun. Jika anda secara tiba-tiba mendapatkan ide yang segar dan orisinil, segera tangkap dengan mencatatnya. ${ }^{1}$

Di Indonesia, hampir semua halaman surat kabar menyediakan rubrik opini. Dan hampir semuanya juga menyediankan honorarium untuk opini yang dimuat. Misalnya Koran Tempo dan Majalah Tempo. Opini-opini ini pun beraneka ragam. Bisa soal masalah sosial, politik, agama, pertanian, perkebunan, pertambangan, hukum, dan lain sebagainya. Penulis dengan latar belakang bidang yang dikuasainya, akan mendapat tempat khusus di media massa jika ia menulis opini tentang bidang yang dikuasainya tersebut. Ini karena dia dinilai memiliki otoritas.

Bahkan, kadang media secara khusus meminta orang tersebut untuk menulis topiktopik tertentu untuk hari-hari tertentu pula. Karena itulah, misalnya, kita mengenal nama

\footnotetext{
$1 \quad$ Bambang Trim, Saya Bermimpi Menulis Buku (Bandung: Penerbit Komunitas Lintas Buku), 8.
} 
Kwik Kian Gie untuk masalah ekonomi, Rhenald Kasali untuk pemasaran dan periklanan, nama Ignas Kleden untuk bidang sosial, nama Mulya Lubis untuk bidang hukum atau nama HS. Dillon untuk bidang pertanian. Juga, misalnya Al Chaidar jika berkaitan dengan NII atau Emerson Yuntho jika berkaitan dengan masalah-masalah korupsi.

Tentu saja mereka ini tidak langsung menjadi penulis opini.Mereka juga belajar, melalui banyak tahap. Tetapi, yang jelas mereka memiliki kompetensi yang membuat masyarakat mengakui, mereka memang layak untuk menulis soal atau masalah yang mereka tulis tersebut.

Dalam Kamus Besar Bahasa Indonesia yang diterbitkan Balai Pustaka, Opini disebutkan sebagai "pendapat", "pikiran," atau "pendirian," Opini memang bisa diartikan sebagai pandangan seseorang tentang suatu masalah. Tidak sekadar pendapat, tetapi pendapat ilmiah. Pendapat yang bisa dipertanggungjawabkan dengan berdasar dalil-dalil ilmiah yang disajikan dalam bahasa yang lebih popular. Karena itulah, untuk menulis opini juga dibutuhkan riset. Riset merupakan penguat dari argumentasi penulis untuk menekankan gagasannya. Opini inilah yang ditulis dan dituangkan dalam bentuk "artikel." Adapun kolom adalah opini yang "lebih cair" dalam gaya bahasanya. Penulis kolom biasanya tidak saja mereka yang dikenal memiliki keahlian dalam bidang yang ditulisnya, tapi juga memiliki style (gaya). Itu sebabnya disebut "kolomnis"

Tulisan opini termasuk jenis karangan argumentasi. Pendapat atau argumentasi penulis perlu disampaikan dengan elegan dan tentunya harus argumentatif. Karangan argumentasi merupakan jenis karangan yang lebih menitikberatkan pendapat yang disertai alasan yang kuat dari penulisnya.

Karangan argumentasi ini merupakan karangan yang mengemukakan argumentasi, alasan, bukti atau contoh yang dapat meyakinkan. Maksud tulisan ini adalah meyakinkan pembaca agar membenarkan pendapat, gagasan, dan keyakinan penulis.

Banyak ahli berpendapat bahwa karangan argumentasi lebih sulit bila dibandingkan dengan jenis karangan lain. Letak kesulitan dalam penulisan karangan argumentasi adalah berupaya untuk meyakinkan orang lain agar terpengaruh dan kemudian bertindak seperti yang diinginkan, tentu ada persyaratannya. Pengarang harus berpikir secara kritis dan logis. Dia harus terbuka menerima pendapat orang lain, lalu menganalisis dan mempertimbangkannya secara baik dan rasional. Agar dapat mengajukan argumentasi, pengarang sudah pasti harus memiliki pengetahuan dan pandangan yang cukup luas tentang yang diperbincangkan. Kelogisan berpikir, keterbukaan sikal, dan keluasan pandangan terhadap masalah, akan berpedan mempengaruhi orang lain. ${ }^{2}$

Penulis argumentasi harus yakin bahwa maksud suatu bagian pendahuluan adalah tidak lain daripada menarik perhatian pembaca, memusatkan perhatian pembaca kepada

Sukino, Menulis itu Mudah, Panduan Praktis Menjadi Penulis Handal (Yogyakarta: Penerbit LKIS, 2010), 70-71. 
argument-argumen yang akan disampaikan, serta menunjukkan dasar-dasar mengapa argumentasi itu harus dikemukakan dalam kesempatan terebut.

Karena sebuah argumentasi harus memancarkan kebenaran atau sebuah tenaga yang kuat untuk mempengaruhi sikap pembaca, maka tidak boleh ada hal-hal yang kontroversial dimasukkan di dalam pendahuluan. Secara ideal pendahuluan harus mngandung cukup banyak bahan untuk menarik perhatian pembaca yang tidak ahli sekalipun, serta memperkenalkan kepada pembaca fakta-fakta pendahuluan yang perlu untuk memehami argumentasinya. Fakta-fakta pendahuluan harus benar-benar diseleksi supaya pengarang tidak melakukan hal-hal yang justru bersifat argumentatif yang baru akan dikemukakan dalam sebuah argumentasi. ${ }^{3}$

Proses menulis sebagai suatu cara berkomunikasi, atau hubungan antara penuli dan pembaca, secara singkat dapat kita utarakan sebagai berikut. Setiap penulis atau pengarang mempunyai pikiran atau gagasan yang ingin disampaikan atau diturunkan kepada orang lain. Dalam hal ini dia harus menerjemahkan ide-idenya itu ke dalam sandi-sandi lisan yang selanjutnya diubah menjadi sandi-sandi tulis. Pengarang memanfaatkan sejumlah sarana mekanis untuk merekam sandi tulis tersebut. Setelah selesai perekaman itu dapatkah diteruskan atau disebarkan kepada orang lain (dalam hal ini para pembaca) melintasi waktu dan ruang. ${ }^{4}$

Salah satu Madrasah Aliyah di Kudus yang gurunya memiliki masalah dalam penulisan Opini adalah adalah Madrasah Aliyah NU Tasywiquth Thullab Salafiyyah (TBS) Kudus. Madrasah Aliyah (MA) Nahdlatul Ulama (NU) Tasywiquth Thullab Salafiyyah (TBS) Kudus didirikan pada 1392 H / 1972 M. Berdiri kokoh di Jl. KH. Turaichan Adjhuri nomor 23 tepatnya di Desa Kajeksan Kecamatan Kota Kabupaten Kudus. Letaknya tidak jauh dari pusat kota (500 meter dari pusat kota).

MA NU TBS Kudus menerapkan Kurikulum 2013 dan kurikulum lokal. Kurikulum lokal inilah yang menjadikan MA NU TBS mempunyai ciri khas tersendiri.MA NU TBS Kudus membuka empat program pendidikan. Program yang dibuka di MA NU TBS Kudus adalah Program Keagamaan (PK), Program Ilmu Pengetahuan Alam (IPA), Program Ilmu Bahasa, dan Program Ilmu Sosial (IPS).

Di MA NU TBS Kudus terdapat banyak permasalahan guru dalam menulis opini. Hasil wawancara dengan guru bahasa Indonesia menjelaskan bahwa, tuntutan penerapan Kurikulum 13 menuntut guru aktif membuat tulisan, salah satunya menulis artikel atau Opini. Di Sekolah tersebut guru masih kesulitan menulis opini dengan baik.

Merujuk pada masalah tersebut, perlu adanya pelatihan dan pendapingan pembuatan penulisan Opini kepada guru. Salah satu alternatif untuk meningkatkan kemampuan guru menulis opini adalah dengan melatih dan memberikan pendapingan bagi guru untuk

Gorys Keraf, Argumentasi dan Narasi (Jakarta: PT. Gramedia Pustaka Utama, 2007), 104-105.

Henry Guntur Tarigan, Menulis sebagai suatu Keterampilan Berbahasa (Bandung: Penerbit Angkasa, 2013), 21-22. 
membuat opini. Dengan pelatihan menulis opini, diharapkan mampu memberikan bekal keterampilan guru untuk membuat tulian opini yang baik dan menarik.

Seorang guru Bahasa Indonesia idealnya mampu dan memiliki keterampilan menulis opini dengan baik. Permasalahan yang ditemukan di MA NU Tasywiquth Thullab Salafiyyah Kudus, guru banyak yang belum bisa membuat tulian opini yang baik. Dengan demikian, kiranya perlu ada upaya untuk mengatasi permasalahan tersebut.

Merujuk kondisi guru bahasa Indonesia diMA NU Tasywiquth Thullab Salafiyyah Kudus, maka berdasarkan hasil wawancara prapelaksanaan pendampingan, ada beberapa permasalahan berikut. Pengetahuan dan keterampilan guru MA NU TBS Kudus dalam membuat tulisan opini sangat rendah. Padahal penerapan kurikulum menuntut guru produktif menulis dan berkarya. Kedua, belum terampil dan terbiasa menulis opini. Ketiga, Guru bahasa Indonesia di MA NU TBS kudus jarang yang tulisannya dimuat di koran. Hal tersebut yang menjadi daya tarik untuk dikaji lebih lanjut tentang bagaimana memberdayakan guru bahasa Indonesia MA NU TBS Kudus dalam Pendampingan. Berdasarkan permasalahan di atas, maka perlu ada upaya mengatasi masalah tersebut. Salah satu alternatifnya dengan melakukan Pelatihan dan Pendampingan menulis opini untuk Guru Bahasa Indonesia MA NU Tasywiquth Thullab Salafiyyah.

Menjadi seoarang penulis memang butuh proses. Jadi, bagaimana caranya menjadi seorang penulis, jawabannya tergantung pada persoalan "dedikasi". Ada tidak keyakinan yang kuat di dalamnya bahwa dengan menlis itu pengabdian dioptimalkan Hanya dengan menulis itulah manfaat hidup (baginya) dapat diberikan kepada orang lain. Dengan demikian menulis membuatnya memiliki martabat, kebanggaan, dan menjunjung tinggi nilai-nilainya. Maka, seseoarang akan berusaha keras untuk konsisten. Dalam keadaan senang ataupun susah, dalam keadaan punya uang atau sedang miskin, dan di mana pun berada, menulis merupakan kebutuhan utamanya. ${ }^{5}$

Menulis merupakan suatu kegiatan yang mempunyai banyak manfaat yang dapat diterapkan oleh penulis itu sendiri. Menurut Sabarti Akhadiah, dkk. (1994: 1-2) ada beberapa manfaat menulis antara lain yaitu: (1) Dengan menulis dapat lebih mengenali kemampuan dan potensi pribadi yang berkaitan dengan permasalahan yang sedang ditulis; (2) Melalui kegiatan menulis dapat mengembangkan berbagai gagasan atau pemikiran yang akan dikemukakan; (3) Dari kegiatan menulis dapat memperluas wawasan kemampuan berpikir, baik dalam bentuk teoretis maupun dalam bentuk berpikir terapan; (4) Permasalahan yang kabur dapat dijelaskan dan dipertegas melalui kegiatan menulis; (5) Melalui tulisan dapat menilai gagasan sendiri secara objektif; (6) Dalam konteks yang lebih konkret, masalah dapat dipecahkan dengan lebih melaui tulisan; (7) Dengan menulis dapat memotivasi diri untuk belajar dan membaca lebih giat. Penulis menjadi penemu atau pemecah masalah bukan sekedar

Redi Panuju, Menulislah dengan Marah, Kiat Sukses Menulis Opini di Media Massa (Bandung: Penerbit Nusamedia, 2008), 22. 
menjadi penyadap informasi dari orang lain; (8) Melalui kegiatan menulis dapat membiasakan diri untuk berpikir dan berbahasa secara tertib.

Dari pendapat di atas, jelas bahwa melalui menulis seseorang akan mampu mengenali potensi yang dimilikinya. Penulis akan mengetahui sampai dimana pengetahuannya tentang suatu topik atau bahan yang akan dibuat tulisan. Untuk mengembangkan topik tersebut, penulis harus berpikir, menggali pengetahuan dan pengalamannya.

Menulis sebuah karangan sederhana secara teknis dituntut memenuhi persyaratan dasar seperti kalau akan menulis karangan yang rumit. Dalam menulis karangan sederhana diperlukan adanya pemilihan topik, membatasinya, mengembangkan gagasan, menyajikannya dalam kalimat dan paragraf yang tersusun secara logis, dan sebagainya. Walaupun demikian, kemampuan menulis bukanlah milik orang yang mempunyai bakat dalam menulis saja. Dengan latihan yang sungguh-sungguh kemampuan tersebut dapat dimiliki oleh siapa saja yang berniat dalam mengungkapkan gagasannya dalam bentuk tulisan.

\section{METODE}

Pengabdian kepada masyarakat ini menggunakan pendekatan Asset Based Community Development (ABCD). Pendekatan ini mencurahkan perhatian pada konsep "gelas setengah isi”, di mana kekuatan, kapasitas, dan asset komunitas digali sedemikian rupa agar semuanya bisa menjadi fondasi yang kuat untuk program pengembangan masyarakat. Pendekatan ini hadir untuk menumbuhkan mental positif serta memberikan semangat bagi masyarakat untuk terbiasa mengeksplorasi diri sendiri. ${ }^{6}$

Terdapat empat langkah kegiatan pengabdian dengan pendekatan ABCD dengan model Appreciative Inquiry (AI). Pertama, discovery atau menemukan. Pada tahap ini dlakukan brainstorming kepada para masyarakat subjek dampingan, tentang berbagai hal yang pernah dicapai dan pengalaman-pengalaman keberhasilan di masa lalu, serta berbagai potensi yang dimiliki masyarakat dampingan. Kedua dream atau impian. Pada tahap ini, para subjek dampingan diajak untuk mengeksplorasi harapan dan impian mereka, baik untuk diri mereka sendiri, organisasi, maupun untuk masyarakat desa. Para peserta diajak untuk memikirkan hal-hal besar dan berpkir out of the box serta membayangkan hasil-hasil yang ingin dicapai, terutama berkaitan dengan menyongsong society 5.0. Ketiga design, merancang. Pada tahap ini, subjek dampingan diajak untuk memulai merumuskan strategi, proses dan sistem, membuat keputusan dan mengebangkan kolaborasi yang mendukung terwujudnya perubahan yang diharapkan, terutama berkaitan dengan pembuatan opini. Pada tahap ini semua hal positif di masa lalu ditransformasikan menjadi kekuatan untuk mewujudkan impian mereka (dream). Keempat, destiny atau pelaksanaan. Pada tahap ini, subjek damping diajak

\footnotetext{
$6 \quad$ Edi Irawan, "Menyongsong Peradaban 4.0 Melalui Pelatihan Pembuatan Website bagi Warga Desa Perbatan,” dalam InEJ: Indonesian Engagement Journal, Vol. 1, No. 1 (2020).
} 
secara bersama untuk mewujudkan mimpi mereka sebagaimana rancangan yang sudah ditetapkan sebelumnya.

\section{ANALISIS DAN PEMBAHASAN \\ Pelaksanaan Program}

\section{Discovery atau Menemukan}

Pada tahap ini, merupakan tahap penggalian informasi kepada masyarakat subjek damping, dalam hal ini adalah guru bahasa Indonesia di MA NU TBS Kudus, tentang berbagai hal yang membanggakan dan tentang prestasi yang pernah diraih serta berbagai bentuk pengalaman-pengalaman keberhasilan di masa lalu terkait dengan pengalaman kegiatan kepenulisan, khususnya menulis opini. Dalam tahap discovery ditemukan berbagai hal positif dan asset yang dapat dimanfaatkan sebagai bahan dalam kegiatan pemberdayaan masyarakat berupat pelatihan dan pendampingan guru dalam menulis. Pertama, asset berupa Sumber Daya Manusia (SDM) yang baik, mereka yaitu para guru bahasa Indonesia di Madrasah Tasywiquth Thullab SalafiyyahKudus yang memiliki banyak potensi untuk dapat lebih dikembangkan menjadi lebih baik. Para guru bahasa Indonesia di madrasah tersebut sudah menempuh studi S1 semua. Guru bahasa Indonesia pendidikannya sudah linier, namun ada juga sebagian guru yang pendidikannya tidak linier bahasa Indonesia. Meskipun demikian, para guru bahasa Indonesia sangat terbuka dengan hal-hal baru yang berkaitan dengan hal-hal yang baik dan positif. Sehingga hal tersebut merupakan potensi penting yang baik untuk modal penting dalam pengabdian kepada masyarakat.

Kedua, asset berupa Perpustakaan sekolah yang memiliki buku cukup lengkap. Kita tahu bahwa kemampuan menulis akan baik jika ditunjang dengan kebiasaan membaca yang baik. Kebiasaan membaca yang baik akan berjalan maksimal jika ditunjang dengan adanya perpustakaan sekolah yang baik dan lengkap. Untuk itu keberadaan perpustakaan di sekolah yang memiliki koleksi buku yang cukup banyak dapat menunjang guru dalam memiliki kebiasaan membaca yang baik.

Ketiga, di sekolah sudah bisa mengakses internet gratis. Dengan kata lain sekolah sudah menyediakan wifi gratis bagi semua guru, sehinga memudahkan guru untuk mengakses informasi secara langsung di internet. Ada banyak informasi bertebaran yang bisa dijadikan ide atau gagasan dalam menulis.

Keempat, di Sekolah tersebut ada majalah sekolah, yang di dalam majalah tersebut ada rubrik opini guru. Keberadaan media tersebut tentu sangat penting dan dapat menunjang guru dalam menulis, setelah menulis guru dapat memanfaatkan media tersebut untuk mempublikasikan karyanya agar bisa dibaca banyak orang.

Kelima, Beberapa guru ada yang sudah memiliki kebiasaan menulis yang baik. Kebiasaan menulis tersebut tentu dapat menjadi asset berharga untuk lebih meningkatkan 
kemampuan menulis guru. Menulis memang suatu kemapuan atau skill yang harus dilatih terus menerus. Untuk itu, pengalaman tersebut menjadi modal penting bagi guru.

\section{Dream atau Impian}

Dalam tahap Dream ini, para subjek pelatihan dan pendampingan yang merupakan guru bahasa Indonesia diajak untuk mengeksplorasi harapan dan impian yang ingin diraih. Harapan dan impian itu tentu bisa untuk diri mereka sendiri, untuk pihak sekolah, maupun untuk masyarakat secara luas. Para guru diajak untuk memikirkan dan memimpikan hal-hal yang besar terutama berkaitan dengan hal-hal seputar kepenulisan. Bahwa menulis merupakan salah satu kegiatan yang sangat bermanfaat. Guru bahasa Indonesia pun banyak yang bermimpi berharap memiliki kemampuan menulis yang baik, dan ada yang ingin menjadi penulis yang produktif. Selain itu mereka juga bermimpi atau berharap tulisan yang dihasilkan dapat bermanfaat bagi masyarakat, dapat memajukan madrasah dan bisa bernilai dakwah. Harapan lainnya adalah, mereka dapat mengamalkan ilmu yang didapat dengan menulis.

\section{Design atau Merancang}

Setelah tahap impian kemudian lanjut ke tahap design. Dalam tahap ini para peserta subjek pelatihan dalam pengabdian ini diajak untuk membuat gambaran atau rancangan terkait dengan cara, strategi, kegiatan yang dilakukan dalam upaya untuk mewujudkan perubahan yang diharapkan, terutama berkaitan dengan kegiatan penulisan, khususnya menulis artikel atau opini yang baik. Dalam tahap ini, semua modal positif atau hal positif di masa sebelumnya di transformasikan agar menjadi kekuaran untuk mewujudkan keinginan atau impian (dream). Keinginan yang baik tentu akan dapat diraih dengan adanya ranacangan, rencana, kegiatan yang jelas dan terukur, evaluasi, dan ada tindak lanjut yang jelas.

\section{Destiny atau Pelaksanaan}

Pada tahap pelaksanaan, para guru-guru dikumpulkan dalam ruangan. Dalam tahap ini para guru bahasa Indonesia diajak untuk merealisasikan keinginannya untuk bisa menulis artikel atau opini dengan baik. Para guru bahasa Indonesia bersama tim pengabdian menyusun strategi dalam pelaksanaan pengabdian ini dengan baik.

Hasil yang dicapai dalam kegiatan ini, secara garis besar terdiri atas: 1) Pendataan, 2) Persiapan Program, 3) Pemaparan materi pengabdian, 4) Praktik Membuat Tulisan, 5) Editing Bersama, 6) Refleksi, dan 7) Follow up. Adapun kegiatan yang telah dilaksanakan adalah sebagai berikut.

a. Tahap Pendataan

Pada tahap ini tim pengabdian melakukan pendataan ke Madrasah Aliyah NU 
Taswiqutthullab Salafiyah Kudus di Kajeksan untuk mencari data guru-guru bahasa Indonesia di Sekolah. Sebelum melakukan pendataan tentunya tim berkoordinasi dengan pihak sekolah dan minta izin pelaksanaan pengabdian. Pelaksanaan pengabdian pun mendapat izin dan sambutan yang baik.

b. Tahap Persiapan Program

Mempersiapkan pendampingan pelatihan pembuatan artikel atau opini yang baik media, dengan membuat materi, koordinasi dengan mahasiswa, koordinasi dengan guru, Persiapan sarana dan prasarana, persiapan tempat, pembuatan materi dan sebagainya.

c. Pemaparan Materi Pengabdian

Pada tahap ini, tim pengabdian menyampaikan materi kepada para guru bahasa Indonesia dalam bentuk Power Point dan juga memberikannya dalam bentuk hardcopy. Para guru bahasa Indonesia diberi penjelasan bagaimana menulis artikel atau opini yang baik, bagaimana cara membangkitkan motivasi menulis, bagaimana cara menulis yang produktif, bagaimana cara mencari ide dan sebagainya. Peserta pun tampak antusias.

d. Praktik Membuat Tulisan

Dalam tahap ini, peserta yang ikut pelatihan kemudian mempraktikkan langsung membuat tulisan. Sebelum mengetik langsung di laptop, peserta diberi kertas dan diminta membuat tulisan dahulu di kertas. Peserta membuat rancangan opini, mencari ide, kemudian menuliskannya. Menulis membutuhkan waktu yang cukup panjang. Dalam praktik menulis ini, peserta dilatih dan dilakukan pendampingan. Bagi peserta yang kesulitan akan dibantu. Setelah membuat tulisan di kertas, kemudian peserta memindahkan tulisan tersebut ke dalam laptop atau mengetikkan langsung. Banyak peserta yang antusias menulis. Tema tulisan yang dibuat beragam, ada yang tema pendidikan, seputar pembelajaran di era Pandemi, Menjaga Kesehatan di Tengah Pandemi, dan sebagainya.

e. Editing

Dalam tahap editing, tulisan yang sudah jadi kemudian diedit bersama. Peserta juga didampingi. Selain itu pendampingan dan editing juga dilakukan secara online, peserta yang telah menulis bisa mengirimkan karyanya lewat email. Kemudian tim pendampingan melakukan revisi karya. Setelah ada revisi kemudian dikembalikan kepada peserta untuk diedit lagi sampai tulisan menjadi lebih bagus.

f. Refleksi

Dalam refleksi, guru-guru peserta pelatihan mencoba mengunggah karya. Sebagian besar karya diunggah di blog. Setelah diunggah kemudian karya karya tersebut kemudian diberikan masukan dan komentar. Selain melakukan refleksi juga masing-masing peserta memberikan apresiasi kepada karya perserta yang 
lain.

7. Tahap Evaluasi Kegiatan (Follow Up)

Evaluasi pada kegiatan pengabdian ini yaitu Tim pengabdian melakukan kegiatan evaluasi, menilai, memberi saran, masukan dan penghargaan terkait hasil pendampingan, simulasi dan kegiatan praktik membuat tulisan artikel atau opini. Dari hasil evaluasi, diperoleh bahwa kegiatan pendampingan dan pelatihan pembuatan tulisan opini untuk guru di MA NU Taswiqutthullab Salafiyyah Kudus berlangsung dengan lancar, aktif, kreatif, efektif dan menyenangkan. Guru-guru di MA NU Taswiqutthullab Salafiyyah Kudus, khususnya guru bahasa Indonesia memperolehpengetahuan tentang cara menulis opini yang baik, selain memperoleh pengetahuan mereka juga mendapatkan pengalaman menulis langsung dengan hasil tulisan yang cukup baik. Semoga pelatihan dan pendampingan tersebut bermanfaat bagi peserta.

Pelaksanaan pengabdian kepada masyarakat mengenai pelatihan dan pendampingan menulis opini secara umum berjalan dengan baik. Secara umum keterampilan menulis itu memang membutuhkan proses yang panjang. Menulis yang bagus tidak bisa instan, butuh proses yang panjang. Namun demikian, setelah pelaksanaan pelatihan dan pendampingan penulisan dilihat gan dari hasil $\mathrm{P}$

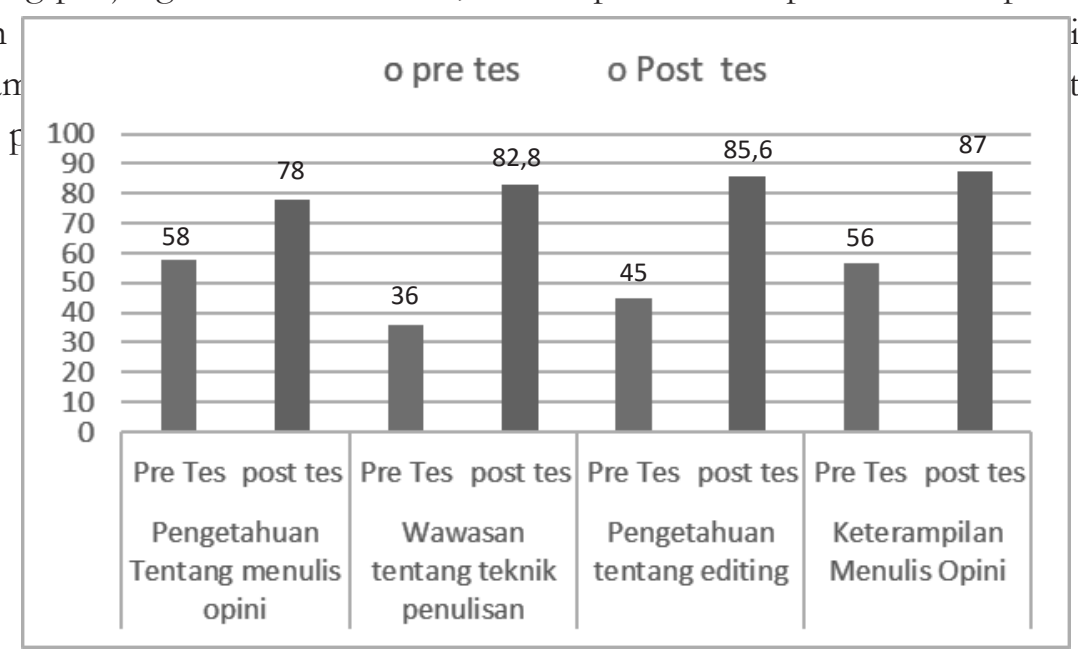
ikut dapat t diketahui

Gambar 1. Grafik Peningkatan Pengetahuan dan Keterampilan Menulis

Berdasarkan hasil pre tes dan post tes dalam grafik, dijelaskan bahwa pengetahuan 
tentang menulis opini peserta sebelum pelatihan rata-rata sebesar $58 \%$, setelah dilakukan pengabdian pengetahuannya meningkat menjadi $78 \%$. Wawasan tentang teknik penulisan peserta sebelum pelatihan rata-rata sebesar $36 \%$, setelah dilakukan pelatihan dan pengabdian meningkat menjadi $82,8 \%$. Pengetahuan tetang editing sebelum pelatihan rata-rata sebesar $45 \%$, setelah pengabdian meningkat menjadi 85,6\%. Keterampilan menulis opini sebelum pelatihan dan pengabdian rata-rata sebesar $56 \%$, setelah dilakukan pelatihan dan pendampingan meningkat menjadi $87 \%$. Dalam pelatihan ini peserta pelatihan pun merasa senang mengikuti pelatihan. Semua peserta menyatakan bahwa pelatihan dan pendampingan penulisan opini memberikan banyak manfaat bagi peserta.

\section{KESIMPULAN}

Pelatihan dan pendampingan penulisan opini bagi guru bahasa Indonesia di Madrasah Aliyah NU Tasywiquth Thullab Salafiyyah Kudus memberikan pengetahuan dan wawasan baru bagi guru, serta mampu meningkatkan keterampilan menulis opini bagi guru bahasa Indonesia. Kelebihan pelatihan ini dapat memberikan bekal positif bagi peningkatan kompetensi guru kaitannya dalam hal tulis menulis. Kekurangannya, kegiatan ini dilaksanakan di masa pandemi covid 19, jadi pelaksanaan kadang sedikit terkendala masalah waktu. Meskipun demikian acara tetap bisa berjalan dengan lancar dan dapat memberikan kebermanfaatan bagi peserta pelatihan.

\section{DAFTAR PUSTAKA}

Akhadiah, S., dkk. (1994). Pembinaan Kemampuan Menulis Bahasa Indonesia. Jakarta: Erlangga. Irawan, Edi. (2020). "Menyongsong Peradaban 4.0 melalui Pelatihan Pembuatan Website bagi Warga Desa Perbatan,” Inej: Indonesian Engagement Journal, 1 (1). 32-33.

Keraf, Gorys. (2007). Argumentasi dan Narasi. Jakarta: PT. Gramedia Pustaka Utama.

Panuju, Redi. (2008). Menulislah dengan Marah, Kiat Sukses Menulis Opini di Media Massa. Bandung: Penerbit Nusamedia.

Sukino. (2010). Menulis itu Mudah; Panduan Praktis Menjadi Penulis Handal. Yogyakarta: Penerbit LKIS.

Tarigan, Henry Guntur. (2013). Menulis Sebagai suatu Keterampilan Berbahasa. Bandung: Penerbit Angkasa.

Trim, Bambang. (2005). Saya Bermimpi Menulis Buku. Bandung: Penerbit Komunitas Lintas Buku. 